\title{
PENINGKATAN KETERAMPILAN SOSIAL PADA ANAK USIA DINI MELALUI PERMAINAN TRADISIONAL BENGKULU
}

\author{
Oleh \\ DINI WIDIYANTI \& \\ RIKA PARTIKA SARI
}

\begin{abstract}
The aims of this research is to get information and data about the effort ti increase children's social skills in grade B kindergarten through playing method of traditional games in PAUD Yasporbi Kota Bengkulu. Research method used action research method. This method conduced in two cycles according to Kemmis and Taggart model which consist of 4 stages (plan, action, observation and reflection). Data collecting tecniques used field notes, interview, documentation and observation. Research subject was taken from 10 children of 5-6 years old. The result of the research shows that children's social skills through playing method of traditional games could increase of grade B kindergarten. Analysis of data obtained from the comparison between pre-percentage increase which showed from pre-intervency the class avarage is $47,70 \%$ up to $79,79 \%$ at posttest result.
\end{abstract}

Keywords: social skills, traditional games.

Abstrak

Tujuan penelitian ini adalah untuk mendapatkan informasi dan data tentang upaya meningkatkan keterampilan sosial melalui permainan tradisional bengkulu di PAUD Yasporbi Kota Bengkulu. Metode penelitian yang dignakan adalah metode Kemmis dan Taggart yang terdiri dari perencanaan, tindakan, observasi dan refeksi. Teknik pengumpulan data yang digunakan adalah observasi, wawancara dan dokumentasi. Subyek penelitian terdiri dari 10 anak berusia 5 -6 tahun. Hasil penelitian ini menunjukkan bahwa keterampilan sosial anak PAUD kelas B melalui metode permainan tradisional sebesar $47,79 \%$ dari praintervensi rata-rata kelas dan $79,79 \%$ pada hasil posttest.

Kata kunci: Keterampilan sosial, permainan tradisonal. 


\section{PENDAHULUAN}

Pendidikan anak usia dini adalah upaya pembinaan yang ditujukan kepada anak sejak lahir sampai dengan usia enam tahun. Pendidikan dilakukan melalui pemberian stimulus agar dapat membantu perkembangan, pertumbuhan jasmani maupun rohani sehingga anak memiliki kesiapan memasuki pendidikan lebih lanjut. Oleh karena itu, pendidikan usia dini merupakan pendidikan yang paling mendasar menempati kedudukan sebagai golden age dan sangat strategis dalam pengembangan sumber daya manusia.

Hal ini sesuai dengan Permen Diknas No. 58 Tahun 2009 dalam Undangundang No.20 Tahun 2003 pasal I, butir 14 yaitu: Pendidikan anak usia dini adalah suatu upaya pembinaan yang ditujukan kepada anak sejak lahir sampai usia enam tahun yang dilakukan melalui pemberian rangsangan pendidikan untuk membantu pertumbuhan dan perkembangan jasmani dan rohani agar anak memiliki kesiapan dalam memasuki pendidikan lebih lanjut.

Pendidikan anak usia dini, khususnya di Taman Kanak-kanak (TK) sangat penting sekali dan merupakan salah satu jenjang pendidikan yang perlu diperhatikan. TK merupakan pendidikan anak usia dini pada jalur formal yang menyediakan program pendidikan anak umur empat sampai enam tahun. Pendidikan tersebut dapat membantu mengembangkan potensi baik psikis maupun fisik yang meliputi nilai-nilai moral dan agama, sosial emosional, kemandirian, kognitif, bahasa, fisik motorik dan seni. Bidang pengembangan pembelajaran di TK, setidaknya dapat dibagi dalam dua hal, yaitu (1) pembentukan perilaku yang meliputi nilai-nilai agama, moral dan sosial emosional, (2) pengembangan kemampuan dasar yang meliputi: daya cipta, bahasa, daya pikir, keterampilan, dan jasmani. Tahun-tahun pertama merupakan waktu yang penting bagi tumbuh kembang fisik anak, perkembangan kecerdasan, keterampilan motorik dan sosial emosinal berjalan demikian cepatnya sehingga dapatlah dikatakan bahwa keberhasilan tahun-tahun pertama untuk sebagian besar menentukan masa depan anak tersebut. Banyak para pakar yang mengingatkan bahwa usia Taman Kanakkanak (TK) merupakan masa keemasan bagi perkembangan kecerdasan anak. 
Hasil penelitian mengungkapkan bahwa sampai usia 4 tahun tingkat kapasitas kecerdasan anak telah mencapai 50\% dan pada usia 8 tahun telah mencapai $80 \%$.

Pendidikan anak usia dini dianggap sebagai cermin dari suatu tatanan masyarakat, tetapi juga ada pandangan yang mengemukakan bahwa sikap dan perilaku suatu masyarakat dipandang sebagai suatu keberhasilan ataupun sebagai suatu kegagalan dalam pendidikan dan keberhasilan pendidikan tergantung kepada pendidikan anak usia dini. Karena jika pelaksanaannya pendidikan pada anak usia dini baik, maka proses pendidikan pada usia remaja, usia dewasa akan baik pula.

Hal ini mengisyaratkan bahwa semua pihak perlu memahami akan pentingnya masa usia dini untuk mengoptimalisasi pertumbuhan dan perkembangan.

Berbicara tentang anak, tidak bisa lepas dengan pentingnya layanan pendidikan yang sesuai dengan kebutuhan dan perkembangan anak. Menurut Yamin dan Sanan (2010:1) anak sehat, cerdas, ceria, dan berakhlak mulia adalah sebait ungkapan yang sarat makna dan merupakan semboyan dalam pengasuhan, pendidikan dan pengembangan anak usia dini di indonesia.Sedangkan menurut Bredekamp dan Regrant (2010: 1) menyimpulkan bahwa anak akan belajar dengan baik dan bermakna bila anak merasa nyaman secara psikologis serta kebutuhan fisik terpenuhi, anak mengkonstruksi pengetahuannya, anak belajar melalui interaksi sosial dengan orang dewasa dan anak lainnya, eksplorasi, pencarian, penggunaan, belajar melalui bermain, unsur perbedaan anak diperhatikan.Pendidikan anak usia dini merupakan salah satu bentuk penyelenggaraan pendidikan yang menitikberatkan pada peletakkan dasar ke arah pertumbuhan dan perkembangan yaitu, koordinasi motorik kasar dan halus, daya pikir, daya cipta, sosial emosional, sikap dan perilaku serta beragama dan bahasa yang disesuaikan dengan tahapan perkembangan yang dilalui oleh anak usia dini.

Hasil observasi pra-penelitian yang dilakukan di anak kelompok B PAUD Yasorbi kota bengkulu ditemukan anak yang suka mengasingkan diri, tidak mau berinteraksi dan bersosialisasi dengan anak lain bahkan cenderung bermain sendiri dan sering membantah. Atas dasar inilah peneliti ingin meningkatkan 
keterampilan sosial anak kelompok B di PAUD Yasporbi Kota Bengkulu melalui permainan tradisonal.Berkaitan dengan hal tersebut di sisi lain Kota Bengkulu memiliki berbagai macam seni dan budayanya diantaranya salah satu adalah permainan tradisonal. Mempelajari permainan tradisonal bagi anak-anak khususnya anak TK, akan sangat menguntungkan karena disamping dapat menstimulasi keterampilan sosial anak, juga membantu pemerintah dalam melestarikan kekayaan budaya bangsa. Khusus bagi anak, pengenalan terhadap permainan tradisional juga memberi andil dalam menumbuhkan pandangan untuk menghargai banyak ragam budaya yang membesarkannya.

\section{KETERAMPILAN SOSIAL}

Keterampilan sosial secara umum merupakan respon-respon dan keterampilan yang memberikan seseorang individu untuk mempertahankan hubungan positif dengan orang lain(Rosenberg, 1992:41). Sejalan dengan pendapat di atas diperkuat oleh Seefeldt dan Barbour (1994:57-59) keterampilan sosial meliputi keterampilan berkomunikasi, berbagi, bekerja sama, dan berpastisipasi dalam kelompok masyarakat. Kemampuan berkomunikasi adalah perilaku-perilaku yang dipelajari untuk digunakan individu dalam situasi-situasi sosial untuk memperoleh dan memelihara penguatan dari lingkungan. Keterampilan sosial diperoleh melalui proses belajar, baik belajar dari orang tua, guru atau teman sebaya dan lingkungan masyarakat.Pendapat diatas disimpulkan bahwa keterampilan sosial adalah kemampuan berkomunikasi, bekerjasama, 
berbagi, berpartisipasi, dan beradaptasi serta mampu memecahkan masalah serta disiplin sesuai dengan peraturan dan norma yang berlaku.

Elksnin dan Elksnin (1992:2) mengidentifikasikan ciri-ciri keterampilan sosial yang meliputi perilaku interpersonal yang berhubungan dengan kesuksesan akademis, perilaku yang berhubungan dengan penerimaan teman sebaya dan keterampilan berkomunikasi. Keterampilan sosial berperan penting dalam kehidupan karena digunakan selama melakukan interaksi sosial seperti memperkenalkan diri, menawarkan bantuan, memberikan dan menerima pujian.

\section{PERMAINAN TRADISIONAL}

Bermain merupakan naluri alamiah yang melekat pada diri anak sejak bayi. Sejak bayi, anak-anak telah memainkan tangan dan jari-jari kaki mereka, benda-benda di sekeliling, memperhatikan gerakan mainan gantung atau cahaya, menggigit, memasukkan benda-benda ke dalam mulut atau memproduksi suarasuara. Seiring pertambahan usia, anak-anak memainkan permainan-permainan yang makin kompleks. Pengenalan mereka atas jenis-jenis mainan makin bearagam. Mereka juga makin akrab dengan permainan-permainan yang membutuhkan keterampilan tertentu dan kerjasama tim. 
Bermain merupakan sarana yang memungkinkan anak berkembang secara optimal. Menurut Carron dan jan Ellen (1992:21) Bermain dapat mempengaruhi semua perkembangan dengan memberikan kesempatan kepada anak untuk belajar tentang dirinya, orang lain dan lingkungannya. Bermain memberikan kebebasan kepada anak untuk berimajinasi, berekplorasi dan menciptakan sesuatu. Sedangkan Menurut Mayesky (1990:196) bermain bagi anak-anak adalah hal yang mereka lakukan sepanjang hari karena hidupnya adalah bermain. Hal ini diperkuat oleh Tedjasaputra (2001: 16) bermain adalah dunia kerja anak usia prasekolah dan menjadi hak setiap anak untuk bermain tanpa dibatasi usia. Berdasarkan pendapat di atas dapat disimpulkan bermain pada masa kanak-kanak merupakan kegiatan sehari-hari yang dilakukan oleh anak yang dilakukan secara menyenangkan.

Menurut Fitriani (2012: 11) Permainan tradisional merupakan sebuah istilah yang digunakan untuk menyebut permainan yang cara memainkannya didapatkan secara turun menurun. Permainan tradisional umumnya dimainkan dengan cara yang sangat sederhana. Alat yang digunakan juga murah dan mudah didapat. Bahkan ada beberapa yang alatnya dapat dibuat sendiri. Sedangkanmenurut Danandjaja (1987:45) permainan tradisonal merupakan salah satu permainan yang turun temurun yang mempunyai banyak variasi sehingga permainan tradisional usianya sudah tua dan tidak diketahui siapa penciptanya. Sejalan dengan pendapat di atas menurut Yunus (1981:12) permainan tradisonal tumbuh dan berkembang berdasarkan kebutuhan masyarakat setempat. Kebanyakan permainan tradisional dipengaruhi oleh alam sekitarnya sehingga menarik dan menghibur sesuai dengan kondisi masyarakat saat itu. 
Karakteristik permainan tradisional adalah permainan tradisonal yang menggunakan alam sekitar sebagai sumber bermain dan sebagai sumber alat permainan yang didukung kemampuan dan kreativitas dalam menggunakan bahan yang ada dilingkungan sekitar yang menjadi alat permainan. Permainan tradisonal ini mengutamakan interaksi sosial, melatih sosial emosional dikarenakan dalam proses bermain anak dituntut untuk jujur, adil dan penuh tanggung jawab. Permainan tradisional memiliki banyak nilai-nilai edukatif dan pesan moral, seperti: nilai-nilai kebersamaan, kejujuran, tanggung jawab, dorongan prestasi, toleransi, keakraban, kreatif, mandiri solidaritas, sportivitas serta taat pada aturan.

\section{CONGKAK}

Congkak adalah permainan yang ada provinsi bengkulu yang memerlukan sebuah alat yang disebut papan congkak. Papan congkak adalah sebuah papan yang terbuat dari kayu atau plastik, papan ini berbentuk oval memanjang dengan 7 lubang di kedua sisinya (anak lubang) dan dua lubang besar di kedua ujungnya (rumah) dan diibutuhkan biji-biji yang terbuat dari buah kobiul atau dapat digantikan dengan kerang (Fitriani, 2012:11).

Cara bermain alat permainan ini dapat dimainkan oleh dua orang. Masingmasing anak mengisi lobang dengan tujuh biji dan memainkannya dengan mengambil biji-biji tersebut dari salah satu lubang untuk kemudian diletakkan satu persatu di masing-masing anak lubang.Menurut Keen (2012:46-47) manfaat bermain congkak yaitu, memberikan kegembiraan bagi anak, melatih kosentrasi anak, melatih kemampuan motorik halus anak, melatih kecermatan, kecekatan dan ketangkasan anak, mengembangkan kemampuan sosial anak karena permainan ini 
dilakukan bersama-sama dengan teman-temannya, melatih anak untuk mematuhi aturan dan sabar menunggu giliran serta anak dapat berpikir cepat dan mengatur strategi agar tidak melakukan kesalahan serta dapat menyelesaikan semua tahapan permainan.

\section{PERMAINAN BULU AYAM}

Permainan ini menggunakan karet dan bulu ayam. Cara bermain bulu ayam ini pemain terlebih dahulu sut untuk menentukan siapa yang akan bermain terlebih dahulu (Fitriani, 2012:12). Pemain yang menang sut akan melambungkan bulu ayam tersebut dengan kakinya dan setelah itu dilambungkan kembali oleh pemain kedua. Permainan ini akan berhenti bila salah satu pemain mendapatkan nilai sebagimana yang disepakati pada awal permainan. Manfaat permainan ini adalah memberikan kegembiraan bagi anak, melatih kosentrasi anak, melatih kemampuan motorik kasar anak, melatih ketangkasan anak, mengembangkan kemampuan sosial anak karena permainan ini dilakukan bersama-sama dengan teman-temannya, melatih anak untuk mematuhi aturan dan sabar menunggu giliran . 


\section{METODE}

Metode penelitian yang digunakan dalam penelitian ini adalah penelitian tindakan (Action Research) atau penelitian tindakan. Dimana penelitian ini bersifat partisipasif dan kolaboratif. Pendekatan kualitatif menjelaskan peristiwa yang dilakukan dalam penelitian ini sehingga mendapat gambaran dan penjelasan yang lengkap dalam pelaksanaan penelitian tindakan. Pendekatan kuantitatif yang digunakan untuk menganalisa data hasil proses belajar mengajar atau membandingkan nilai peserta didik sebelum dan sesudah penelitian tindakan dilakukan. Nilai ini akan diuji kebenarannya melalui metode tersebut untuk melihat seberapa besar signifikan peningkatan nilai sebelum dan sesudah dilakukan tindakan.

Penelitian tidakan ini menggunakan metode penelitian Kemmis dan Taggart. Dimana rancangan penelitian ini melalui dua siklus, dimana setiap siklus mempunyai langkah-langkah yang harus dilalui peneliti dan partisipan. Rancangan penelitian yang digunakan sesuai dengan kaidah-kaidah penelitian dan kebutuhan pengukuran terhadap parameter penelitian. Penelitian tindakan ini dilakukan sebagai upaya perbaikan terhadap suatu praktek pendidikan melalui pemberian tindakan dan meningkatkan praktek-praktek pembelajaran di kelas secara profesional. Menurut Cormark penelitian tindakan adalah cara melakukan penelitian dan berupaya bekerja untuk memecahkan masalah pada saat bersamaan.

Penelitian tindakan melalui kegiatan pembelajaran dapat dilakukan dengan tahapan yang terdiri dari: (1). Perencanaan, (2). Tindakan, (3). Pengamatan, (4). Refleksi. Pada tahap refleksi, dapat dilihat peningkatan yang terjadi akibat dari 
intervensi tindakan yang diberikan dan memungkinkan untuk melakukan perencanaan tindakan lanjutan untuk siklus berikutnya.

\section{Gambar Metode Penelitian Kemmis dan Taggart}

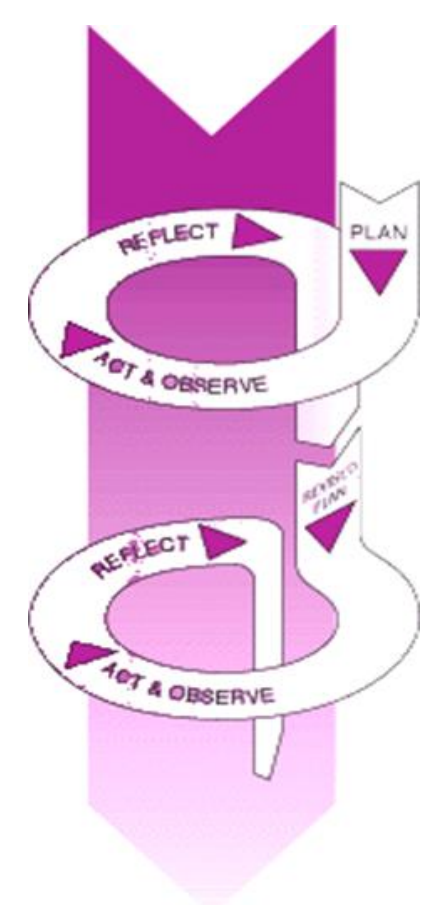

\section{HASIL DAN PEMBAHASAN}

Berdasarkan hasil analisis secara kualitatif, penelitian ini memperoleh peningkatan keterampilan sosial melalui permainan tradisional bengkulu pada anak Kelompok B PAUD Yasporbi Kota Bengkulu dari pra-intervensi dengan rata-rata keterampilan sosial sebesar $49,79 \%$ mengalami peningkatan pada siklus I sebesar $15 \%$ dengan rata-rata peningkatan keterampilan sosialanak mencapai 
64,79\%. Selanjutnya, dari siklus I ke siklus II peningkatan keterampilan sosial anak mencapai $15 \%$ dengan rata-rata hasil peningkatan keterampilan sosial anak mencapai $79,79 \%$.Seperti yang telah disepakati bersama antara peneliti dan kolaborator jika persentase rata-rata peningkatan yang diperoleh mencapai $71 \%$ dari pra-intervensi, maka penelitian dinyatakan berhasil. Akan tetapi, jika belum mencapai peningkatan sebesar 71\%, maka akan dilanjutkan pada siklus selanjutnya. Dapat diketahui bahwa anak Kelompok B PAUD Yasporbi Kota Bengkulu sudah mulai tertarik pada kegiatan pengembangan keterampilan sosial melalui permainan tradisonal bengkulu.

\section{KESIMPULAN}

Berdasarkan analisis mengenai pelaksanaan kegiatan keterampilan sosial melalui permainan tradisonal bengkulu dalam meningkatkan keterampilan sosial anak kelompok B PAUD Yasporbi Kota Bengkulu, dapat disimpulkan sebagai berikut.

1. Didapat persentase peningkatan keterampilan sosial anak mencapai $49,79 \%$ dari pra-intervensi atau asesmen awal kemudian mengalami peningkatan pada keterampilan sosial sebesar $15 \%$ sehingga rata-rata keterampilan sosial pada siklus I menjadi 64,79\%. Selanjutnya, pada siklus II terjadi peningkatan keterampilan sosial sebesar $15 \%$ sehingga didapat rata-rata keterampilan sosial anak menjadi $79,79 \%$.

2. Dari data siklus II, kenaikan persentase sudah mencapai $79,79 \%$ dari praintervensi. Hal ini membuktikan bahwa peningkatan keterampilan sosial anak melebihi standar yang sudah disepakati antara peneliti dan kolaborator yaitu 
sebesar $71 \%$. Berdasarkan hal tersebut menunjukkan bahwa penelitian ini sudah berhasil.

3. Penelitian ini diawali dengan melakukan asesmen awal untuk melihat keterampilan sosial anak. Instrumen yang digunakan untuk melihat keterampilan sosial tersebut dikembangkan oleh peneliti berdasarkan rujukan dari beberapa teori yang telah disimpulkan. Instrumen dikembangkan oleh peneliti dikarenakan guru belum pernah membuat istrumen khusus untuk keterampilan sosial anak. Berdasarkan hasil asesmen awal tersebut, peneliti bersama kolaborator merancang tindakan untuk meningkatkan keterampilan sosial anak. Selain melakukan observasi awal, peneliti juga melakukan wawancara kepada kepala sekolah, guru dan anak.

4. Permainan tradisonal bengkulu yang digunakan dalam penelitian ini yaitu permainan congkak dan gasing yang memiliki karakteristik permainan yang mengasah dan mampu memberikan stimulus kepada anak dalam berinteraksi dengan teman sebaya berupa kebersamaan, berbagi, berkumunikasi serta kemampuan beradaptasi. Guru berperan sebagai fasilitator dan motivator untuk mmeberikan bimbingan, arahan, dan motivasi serta penguatan berdasarkan kebutuhan anak. 


\section{SARAN}

Hendaknya lembaga PAUD dapat lebih memperhatikan peningkatan keterampilan sosial pada anak dengan kegiatan yang menyenangkan. Keterampilan sosial anak merupakan salah satu keterampilan yang dapat digunakan oleh anak untuk menyampaikan ide maupun gagasan yang dimilikinya. Guru dalam pembelajaran hendaknya dapat merancang kegiatan keterampilan sosial melalui kegiatan yang lebih kreatif sehingga anak tidak cepat bosan dan jenuh. Sedangkan orang tua, diharapkan dapat memberikan stimulasi kegiatan keterampilan sosial yang sama di rumah kepada anak sebagai bentuk keberlanjutan program kegiatan yang diberikan oleh guru di sekolah. Dengan adanya kerjasama pihak sekolah dan orang tua, anak akan mendapat stimulasi yang sama dan peningkatan keterampilan sosial yang diharapkan dapat tercapai. Peneliti lain diharapkan lebih memperkaya kajian-kajian penelitian terkait peningkatan keterampilan sosial anak dengan menemukan berbagai kegiatan yang tepat dan sesuai dengan perkembangan anak usia dini, baik yang dilaksanakan di maupun di tingkat SD awal.

\section{DAFTAR PUSTAKA}

Achroni, Keen, 2012. Mengoptimalkan Tumbuh Kembang Anak melalui Permainan Tradisional. Jakarta:Buku Kita.

Carron, Carol E. \& Ellen Jan, 1992. Early Childhood Curricullum: creative play model. New jersey, USA: prentice.

Danandjaya, James, 1987. Folklore Indonesia. Jakarta: Gramedia.

Elksnin \& Elksnin, 1992. Keterampilan sosial pada anak (http:fajar.multiply.com/journal/item/191) (diakses 5 Desember 2018). 
Fitriani, Rahmi, 2012.Seni Dan Budaya Masyarakat Bengkulu. Bekasi:.Rafa Aksara.

Handini, Myrnawati Crie, 2012. Metodologi Penelitian Untuk Pemula. Jakarta: FIP PRESS.

Hurlock, Elizabeth B, 1997. Perkembangan anak jilid I, Alih Bahasa Meita sari \& Muslihah Zarkasih. Jakarta: Erlangga.

Kementrian Pendidikan Nasional, 2010. Pedoman Pengembangan Silabus Di Taman Kanak-Kanak. Jakarta: Direktorat pembinaan TK dan SD.

Mayesky, Mary, 1990. Creative activities for young children. Fourth edition. Newyork: delmar publishers inc.

Moeslichatoen, 2004. Metode Pengajaran di Taman Kanak-kanak. Jakarta: PT.Rineka Cipta.

Moleong, Lexy J, 2007. Metodologi Penelitian Kualitatif Edisi Revisi. Bandung,PT.Remaja Rosdakarya.

Mulyasa, 2012. Praktik Penelitian Tindakan Kelas, Bandung: PT.Remaja Rosdakarya.

Musfiroh, Tadkiroatun, 2008. Cerdas Melalui Bermain (Cara Mengasah Multiple Intelegencce Pada Anak Usia Dini. Jakarta: PT.Grasindo.

Papalia, Diane E., Sally Wendkos olds., dan Ruth Duskin Feldman. 2009. Human Development (perkembangan manusia). Alih bahasa Brian Marswendy. Jakarta: Salemba Humanika.

Purwanto, M. Ngalim, Prinsip-Prinsip dan Teknik Evaluasi Pengajaran. Bandung: PT.Remaja Rosdakarya, 2009.

Rosenberg, michael S.,et.al.,1992. Educating students with behavior reader. New jersey: Prentice hall.

Santrock, John, 2012. life-span Development (Perkembangan Masa Hidup Jilid I ) Jakarta: Erlangga.

Seefeldt, Carol dan Nita Barbour, early childhood education.1994. An introduction . third edition new york: macmillan college publishing company. 
Sugiyono, 2010. Metode Penelitian Pendidikan (Pendekatan Kuantitatif, kualitatif, dan $R \& D$ ). Bandung: Alfabeta.

Tedjasaputra, Mayke S. 2001. Bermain mainan dan permainan. Jakarta: PT.Grasindo.

Yamin, Martini dan Jamilah Sabri Sanan. 2010. Panduan pendidikan anak usia dini (PAUD). Jakarta: Gaung Persada (PG) Press. 